\title{
Understandings of Social Innovation within the Danish Public Sector: A Literature Review
}

\author{
Ada Scupola ${ }^{1, *}$, Lars Fuglsang ${ }^{1}{ }^{1}$, Faiz Gallouj ${ }^{2}$ and Anne Vorre Hansen ${ }^{3}$ \\ 1 Department of Social Science and Business, Roskilde University, 4000 Roskilde, Denmark; fuglsang@ruc.dk \\ 2 Faculty of Economic and Social Sciences, University of Lille, 59000 Lille, France; faiz.gallouj@univ-lille.fr \\ 3 Department of People and Technology, Roskilde University, 4000 Roskilde, Denmark; vorre@ruc.dk \\ * Correspondence: ada@ruc.dk
}

check for updates

Citation: Scupola, Ada, Lars Fuglsang, Faiz Gallouj, and Anne Vorre Hansen. 2021. Understandings of Social Innovation within the Danish Public Sector: A Literature Review. Administrative Sciences 11: 49. https://doi.org/10.3390/admsci 11020049

Received: 23 March 2021

Accepted: 9 April 2021

Published: 1 May 2021

Publisher's Note: MDPI stays neutral with regard to jurisdictional claims in published maps and institutional affiliations.

Copyright: (c) 2021 by the authors. Licensee MDPI, Basel, Switzerland. This article is an open access article distributed under the terms and conditions of the Creative Commons Attribution (CC BY) license (https:// creativecommons.org/licenses/by/ $4.0 /)$.

\begin{abstract}
Social innovation is an emerging theme within innovation theory, and so is the concept of public service innovation networks for social innovation (PSINSIs). The purpose of this article is to explore how social innovation in Danish public services is conceptualised and enacted through the lenses of public service innovation networks for social innovation. To do this, a thorough integrative review of the literature dealing with the Danish context is conducted. The Danish context is interesting in order to investigate these network arrangements, firstly because they are not well understood in the context of the Nordic welfare states, which Denmark is part of, and then because municipalities and civil society have historically had a mutually dependent relationship in Denmark. The article highlights that social innovation is framed in several ways in the Danish public sector. In particular, the results show that the literature can be grouped according to four themes: (1) samskabelse (co-creation), (2) collaboration with civil society, (3) social entrepreneurs and social innovation and (4) public-private innovation partnerships. Moreover, the article presents and discusses a number of Danish empirical projects that may be understood through the lens of the PSINSI framework. Hence, the paper contributes with new theoretical perspectives, in addition to contributing to practice.
\end{abstract}

Keywords: social innovation; public sector; networks; integrative review

\section{Introduction}

This article explores the perceptions of social innovation in public services through the theoretical framework of public service innovation networks for social innovation (PSINSIs) (Desmarchelier et al. 2020). PSINSIs are described as multi-agent collaborative arrangements that develop within public services either in the sectoral sense of the term or as public service in the functional sense, i.e., services of general interest. They are theorised as networks that mobilise a variable number of public and private agents, in particular citizens, in order to co-produce social innovations in response to complex societal problems (Desmarchelier et al. 2020).

Taken together, social innovation, innovation in public services and the network as a mode of organising innovation have attracted (relatively) little attention in the literature. The emerging importance of these topics is driven by recent research in different disciplinary fields. For example, in the field of innovation studies, one example would be the "the shift from visible innovation to dark innovation" and "the shift from innovation in manufacturing to innovation in services" (Martin 2015). In the field of "service innovation studies", examples would include research concerning "service innovation and social innovation" and "service innovation in forgotten sectors" (including public sectors) (Djellal and Gallouj 2018). Finally, in the field of public administration, the paradigm shifts from traditional public administration to new public management and then to new public governance reflect the rise to prominence of collaborative innovation in public services and the networked organisation of production and innovation (Kelly et al. 2002; 
Osborne 2006, 2010; Voorberg et al. 2015; Scupola and Zanfei 2016; Crosby et al. 2017; Mergel 2018; Desmarchelier et al. 2019; Torfing 2019).

Our aim in this paper is to explore how social innovation in Danish public services is conceptualised and enacted through the lenses of public service innovation networks for social innovation (PSINSIs). To do this, we use the four main dimensions developed by Desmarchelier et al. (2020) of different forms of innovation networks to analyse the results of a comprehensive review of the theoretical, empirical and grey literature on the understanding and role of social innovation in a Danish public sector setting. These four dimensions include the main sector in which the network is deployed, the types of agents involved, the role of the public agent and the main form of the innovation pursued. The Danish context is relevant to study since Denmark adheres to the Nordic welfare state model (Esping-Andersen 1990) of publicly funded and administered egalitarian public services. Since the 1970s, this model has been challenged by the injunction of market-inspired mechanisms, more effective administration and decentralisation of public authority (Swank 2000). However, Ibsen and Espersen (2016) argue that throughout history, Danish municipalities and civil society have always had a mutually dependent relationship; it is almost impossible to understand the State (and municipalities) without civil society or civil society without the State.

However, it is still not well understood what the perception of social innovation relative to public services is. In this article, we interpret public services in a broad sense both as a specific service function produced or co-produced by public sector agents as well as-more broadly-tasks that can be developed and carried out by other actors outside the public sector. The public sector as an agent can therefore have several roles in spurring networks for social innovation, as, for example, provider, co-producer, facilitator or supporter of an innovation and the network involved.

The article is structured as follows. First, we provide a theoretical discussion of the concept of a PSINSI and highlight its operating principles. Then we describe the method used to conduct the literature review. This is followed by a presentation of the four themes identified in the literature. Finally, we provide an analysis and discussion of the results and offer some concluding remarks.

\section{Public Service Innovation Networks for Social Innovation (PSINSIs): A Theoretical Understanding}

Innovation studies have gradually shifted their analytical focus from visible to invisible innovation and from the individual entrepreneur to the network (via the organisation) (Martin 2015; Djellal and Gallouj 2018). It can be said that the PSINSI concept is the latest result of this analytical development, and it is devoted to a form of innovation that has long remained invisible and neglected, namely social innovation (Desmarchelier et al. 2020) and its role in solving public tasks.

An innovation network describes a system of relationships between different agents whose purpose is innovation. The agents in question do not all have to belong to the same organisation (otherwise this group of agents would simply be a hierarchy), and the relations that link them can take different forms (cooperation, coordination, collaboration, co-creation, co-production, co-innovation, co-design, etc.), the definitions of which have been the object of an extensive literature (Pestoff et al. 2006; Keast et al. 2007; Sørensen and Torfing 2013; Voorberg et al. 2015; Agger and Lund 2017). Desmarchelier et al. (2020) propose a simple typology of different forms of innovation networks. The typology is based on the following different dimensions: (1) the main sector in which the network is deployed, (2) the types of agents involved, (3) the role of the public agent in the network and (4) the main form of the innovation pursued. The PSINSI framework is a way of conceptualising types of public innovation networks, with a specific focus on a particular form of innovation: social innovation. However, such multi-agent collaboration for social innovation can take place without even the participation of a public actor, e.g., privateprivate networks. We suggest that it is not uncommon for a network to be formed precisely due to the absence of a public solution to a given social problem. This absence may be 
voluntary or involuntary. Indeed, it may result from a general principle of disengagement of the State in favour of social entrepreneurship or the market sector. However, it can also be the consequence (which is not necessarily independent of the previous principle) of the inability of the State to take charge of certain problems due to a lack of resources.

The citizen plays a central role in PSINSIs. Three different types of citizens are distinguished depending on how they are affected by the problem whose solution prompts innovation. Type 1 citizens are directly affected by the problem that generates social innovation and collaboration. Examples include the dependent elderly person, the drug addict, the early school leaver, the refugee, the homeless person, the demented person, and so on. Type 2 citizens are only indirectly affected. These are mainly the relatives and family of the type 1 citizen. Type 3 citizens are not affected by the problem (neither directly nor indirectly) but are sensitive to the problem out of empathy and solidarity or for ideological, philosophical or political reasons. These three types of citizens can take part in the innovation process in different ways. Type 1 citizens rarely (or passively) take part in the collaborative innovation process at work due to their fragility and lack of resources. Types 2 and 3 citizens may be involved in all the stages of the innovation process, either individually or within third-sector organisations. The most active participants represented in the PSINSIs are mainly volunteers and initiators of certain networks and belong to type 2 and 3 citizens.

Public administration, when present, can play two different roles in innovation networks of any kind: an operational role consisting of active collaboration in the production and implementation of innovation (co-production) and a role of support or facilitator (metagovernance) of innovation. Thus, in traditional innovation networks, public administration is involved mainly through the establishment of regulations and financing systems that are favourable to innovation and networking. In PSINSIs, this meta-governance role is not excluded, but what is most important is the fact that public administration, if involved, actively (i.e., operationally) participates in innovation that directly concerns its own sphere of activity (the public service itself).

PSINSIs describe a network that develops a particular type of innovation: social innovation. The literature does not provide a stable and unanimous definition of social innovation. It is generally agreed that social innovation provides new social solutions to social problems. It is therefore social in its means and ends (OECD 2000; Gallouj et al. 2018). It differs from traditional economic and market innovation in that its objective is not to maximise the innovator's profit but to increase the quantity and quality of life of citizens through social mobilisation, transformation of social relations, inclusion and environmental protection (OECD 2000; Simon et al. 2015). Social innovation often emerges as a response to so-called wicked problems, i.e., complex, multifaceted and systemic problems that encompass different societal fields and require the resolution of multiple problems at once, and therefore the mobilisation of different agents with complementary skills. This applies to areas such as the elderly, minorities (especially refugees), long-term unemployment, school dropouts, etc.

Social innovation covers several types of innovations linked by different relationships; here are some of the traditional types mentioned in the literature: product/service innovation, process innovation and organisational innovation. However, it can also, particularly in the field of public services, encompass other types of innovation such as policy, conceptual and systemic (or network) innovations. Policy innovation refers to the development of new regulations, new modes of governance, new forms of participation and behaviour (Hartley 2005; Bekkers et al. 2006, 2014). Conceptual innovation is the development or implementation of new systems of thought and new ways of seeing the world, at different levels, including paradigmatic levels (e.g., new public management, new public governance). Finally, systemic or network innovations are particular forms of organisational innovation that entail the implementation of new ways of collaboration or the improvement of existing ones (Halvorsen et al. 2005). 
However, whereas research has begun to highlight the role of social innovation for addressing public tasks, it is still unclear whether and how it is accepted by the public sector and how it may help public sector to address public needs. For example, it is unclear who the actors are, whether the public sector remains dominant, what types of innovations these networks provide and which parts of society and economy are concerned.

\section{Method}

Conceptual and literature review articles are important to researchers and practitioners, especially in areas that are in an emergent stage. These types of papers consolidate past research as well as line up research opportunities (Sengupta et al. 2017), thus forming a strong foundation for the progress of empirical and conceptual research on emerging phenomena (Webster and Watson 2002). Sengupta et al. (2017) state that integrative reviews are especially appropriate in addressing concepts and phenomena that are of an emerging nature. Therefore, to get and provide a comprehensive understanding of the emerging phenomenon under study, we conducted an integrative review. In addition, this type of review is particularly suitable for our study as "integrative reviews are the broadest type of research review methods allowing for the simultaneous inclusion of experimental and non-experimental research in order to more fully understand a phenomenon of concern. Integrative reviews may also combine data from the theoretical as well as empirical literature. In addition, integrative reviews incorporate a wide range of purposes: to define concepts, to review theories, to review evidence, and to analyse methodological issues of a particular topic" (Whittemore and Knafl 2005, p. 547). In conducting our review, we broadly followed the five stages of the integrative review process: a problem formulation stage, a literature search stage, a data evaluation stage, a data analysis stage and a presentation stage (Cooper 1998; Whittemore and Knafl 2005). Given the emergent nature of the phenomenon under consideration, this study surveys a pool of research papers and reports about public innovation focusing on social innovation and cross-sectorial collaboration in Denmark, irrespective of whether they are empirical or theoretical, qualitative or quantitative research, peer-reviewed academic articles or grey literature (https: / /libguides.rgu.ac.uk/greyliterature, accessed on 5 March 2021). This search strategy ensured the location and identification of all studies relevant to the phenomenon under consideration. Grey literature can provide data not found within commercially published literature, thus facilitating a more balanced view of the evidence (Paez 2017). Locating the proper and reliable sites was one major drawback of including grey literature, together with being a time-consuming process as the search resulted in many duplicates of the same documents. Another major drawback was the dynamic nature of website domains and addresses, as organisations may change names or merge, which may reduce the reproducibility of the grey literature searches. Given our interest for the Danish context, we searched for documents written both in Danish and in English and the search strategy involved access to Google and websites of key Danish organisations and portals producing or storing peer-reviewed and grey literature on the subject. The websites of the key Danish organisations were selected on the basis of thorough discussions with librarians and experts in the field.

These included the Danish National Research Database (a single entry point for Danish research); Bibliotek.dk, which is a common portal for all types of Danish libraries (public libraries, specialised libraries and academic libraries); Local Government Denmark (KL); the Ministry of the Interior and Housing; the Ministry for Social Affairs and Senior Citizens; the National Institute for Local Government Analysis and Research (KORA); and the Danish Center for Social Science Research (VIVE).

Concerning the research chain, we used the main search string "social innovation" and looked for the literature dealing with collaborative approaches to social innovation involving public sector partners in collaboration with other partners. This choice was justified by the aim of the study and the theoretical background. Therefore, the search string "social innovation" was used in combination with other keywords such as "public-private 
innovation networks for social innovation (PSINSI)", "collaborative innovation", "public service", "public service collaboration", "volunteers", "municipalities" and "public-private innovation partnerships". Inclusion and exclusion criteria were also set. The main inclusion criteria were full texts, accessibility and relevance for the phenomenon under investigation. The main exclusion criteria included abstracts, social policy statements, welfare policies, business cycle news, economic analysis statements and reviews of budgets.

The search process generated 4184 hits, which after screening the title and abstract resulted in 225 reports and academic articles (see Appendix A). These were again screened in depth for relevance, first by looking at abstracts and the introduction and, when in doubt, by quickly looking through the whole report by two of the authors. Duplications across websites were removed. A total of 23 highly relevant reports and articles dealing with social innovation resulting from public service innovation networks efforts (PSINSI perspective) were shortlisted and reviewed (see Appendix B). These were subject to a theoretical thematic analysis guided by the PSINSI framework. The analysis was conducted in collaboration between two of the authors following the recommendations of Braun and Clarke (2006). First, the authors familiarised themselves with the material by screening all articles and reports. Second, initial themes were identified through iterations between the authors. Third, the articles were reviewed and the themes were adjusted and merged several times until there was a clear agreement concerning the following four themes: (1) samskabelse (co-creation), (2) collaboration with civil society, (3) social entrepreneurs and social innovation and (4) public-private innovation partnerships. Finally, the selected material was analysed through the theoretical framework of public service innovation networks for social innovation (PSINSIs).

\section{Results}

Our search showed that the phenomenon is new, and hence the scholarly literature is scarce and most of the literature is grey literature reporting results of specific projects. This section presents the findings of the literature review by summarising, analysing and grouping the selected studies into the four identified themes: (1) samskabelse (co-creation), (2) collaboration with civil society, (3) social entrepreneurs and social innovation and (4) public-private innovation partnerships. The first theme is primarily conceptual, whereas the latter three are mainly based on empirical examples.

\subsection{Theme 1: Samskabelse (Co-Creation)}

Samskabelse has been a prominent term in the Danish literature on public innovation. Samskabelse literally means co-creation. In the Danish literature, samskabelse has been used in connection with the concept of "collaborative innovation" (Torfing 2016) and the related concept of co-production. Co-creation/samskabelse, therefore, refers both to crosssectorial collaboration for innovation and to user/citizen involvement in service delivery.

Agger and Tortzen (2015) review the international literature on samskabelse to qualify the Danish debate on how citizens and public actors can develop public welfare together. Building on previous literature), the authors define co-creation as the active involvement of citizens in public service delivery by creating sustainable partnerships with citizens. In a Danish context, Agger and Tortzen (2015) distinguish two normative views on co-creation: (1) efficiency (new public management)-oriented co-creation, through which the user is mobilised to produce part of the service to make it more efficient, and (2) democratic co-creation related to the concept of new public governance. The two approaches are summarised in Table 1. 
Table 1. Views on co-creation according to Agger and Tortzen (2015).

\begin{tabular}{|c|c|c|}
\hline Governance Paradigm & New Public Management & New Public Governance \\
\hline Focus & Product (output) & Process and outcome \\
\hline Benefits & $\begin{array}{c}\text { Efficiency } \\
\text { (value for money) }\end{array}$ & $\begin{array}{l}\text { Democracy } \\
\text { Empowerment } \\
\text { Innovation }\end{array}$ \\
\hline Who participates & Individual citizens & $\begin{array}{c}\text { Citizens } \\
\text { Civil society } \\
\text { Local society }\end{array}$ \\
\hline Where in the policy cycle & Output side: welfare services & Output and input: services, priorities, political governance \\
\hline
\end{tabular}

According to Agger and Tortzen (2015), empirical research shows that co-creation is driven by the public sector and citizens are involved at the later stages of co-creation. Citizens' co-creational work may sometimes replace public services (such as self-help groups), or it may have the character of supplementary co-creation (e.g., parents helping their children with schoolwork). As such, co-creation may challenge exiting roles and relations between policymakers, professionals and citizens and thereby lead to the creation of new roles.

At an organisational/municipal level, Pedersen-Ulrich (2016) worked out a typology of different forms of co-creation: governed co-creation, responsibilising co-creation, equal dignity co-creation and facilitated co-creation. Governed co-creation takes place when municipal actors have an ambition to manage the process of co-creation so that the outcome of the process becomes predictable. Responsibilising co-creation takes place when the municipal actors manage the process, while playing a retrenched role by leaving the main responsibility for the content to external actors-such as citizens, companies or civil society organisations. Equal dignity co-creation is defined as the municipality not having the ambition to control the outcome of the co-creation process, whilst still playing a central role in the process of co-creation. The municipality defines a problem that it wants to solve through a co-creation process. Facilitating co-creation takes place when the result of co-creation is not provided in advance; the municipal actors play a limited role and leave the main responsibility for the content of co-creation to external actors.

Another take on samskabelse/co-creation is through the lenses of innovation. Torfing et al. (2017) developed a theory of "collaborative innovation" (Sørensen and Torfing 2011; Torfing 2016) emphasising collaboration between various types of public and non-public actors (the State, regions, municipalities, self-governing institutions, experts, private companies, interest groups, civil society associations, users, citizens, etc.). They describe collaboration as a driver of innovation and argue that when players with different types of experience, professional knowledge, resources, competencies and ideas are brought together in constructive collaboration over time, it often contributes to a better understanding of problems, alongside greater idea richness, more thorough selection and testing of new solutions, better coordinated implementation and shared ownership of new and daring solutions.

The literature reveals that it is still difficult to measure the empirical impact of cocreation. Agger et al. (2018) focus on measuring and documenting the value of co-creation. They claim that a normative approach to co-creation stemming from research and practitioners has leveraged expectations about co-creation to create positive gains for both society and individuals. They outline four bottom lines for measuring outcomes: democracy, efficiency, innovation and public value. To address the measurement issue, Torfing et al. (2017) focused more on innovation capabilities and conduct an empirical testing of a measuring instrument in 24 crime prevention projects in the Municipality of Copenhagen. The study shows that collaboration has a clear impact on innovation and that innovation leads to an increased crime prevention effect. However, according to Torfing et al. (2017), there is a 
tendency to either measure the result and the effect or measure the process and the use of specific methods.

In sum, the Danish literature on samskabelse/co-creation describes different types of co-creation, provides guidelines for how to organise co-creation and discusses how to measure its impact.

\subsection{Theme 2: Collaboration with Civil Society}

This theme concerns collaboration among public sector professionals, citizens and civil society at large in the production and delivery of welfare services. This section sheds light on these different terms from a theoretical point of view as well as on how these collaborative forms take place empirically in a Danish context.

Andersen and Espersen (2017) argue that there has been an increasing interest in new ways of establishing collaborations between citizens and professionals to produce and deliver new or improved welfare services. Different related concepts are used for these co-operation structures: co-creation, co-production, partnerships, private-public partnerships, citizen budgets, networking and youth panels (Socialstyrelsen 2017). Andersen and Espersen (2017) discuss benefits and challenges in the various types of partnerships. Their article also shows how the collaborative wave is far from new but has characterised the development of welfare benefits in Denmark over many decades. Andersen and Espersen (2017) point out the development of a pragmatic approach to collaboration with civic actors and provide an international perspective on the new forms of cooperation.

However, they argue that in recent years, the relationship between municipalities and civil society has moved from a largely parallel relation to an even more common practice. The municipalities and civil society experiment with new configurations of co-operation and interaction. Expectations for these new collaboration forms are great, yet there is no knowledge as to the extent and nature of the municipalities' cooperation with civil society, how the different forms of cooperation function or what forms of cooperation create value to whom and whether the value is, for example, social, democratic, economic or innovative. The study is the first attempt to generate a systematic insight into the extent and nature of new collaborations in and around Danish municipalities across administrative areas. Next, a number of other concrete examples and perspectives on the phenomenon are given.

Andersen et al. (2014) develop a so-called Oresund model or NEO model, which is a normative model to reduce youth unemployment across the Øresund region. NEO stands for cross-sectoral cooperation between NGOs, businesses and public institutions. It is a cross-sectoral employment method/model that can help reduce youth unemployment. The model is based on successful collaborations between NGOs, industry and public authorities, and it is based on the consideration that good results can be achieved where different complementary resources and competencies come into play. The NEO model suggests that all actors around young people, such as municipalities, companies, NGOs and family/networks, must work together to establish relationships with young people through which their opinions and experiences are heard and given importance.

Ankestyrelsen (2010) investigated the funding that Danish municipalities have released in 2009 in support of voluntary social work according to the Service Act. It is concluded that nearly one-third of the municipalities paid more for voluntary social work than they received in grant from the government, whereas almost every fourth municipality paid less than $50 \%$ of the amount it received in government grants. A replication of the study in 2012 showed the same results (Ankestyrelsen 2013).

Espersen (2016) evaluates the project Bookstart, a nationwide initiative with $20 \mathrm{mu}$ nicipal libraries, which distribute age-matched book packages to families and children in vulnerable residential areas. The evaluation finds that in future preventive efforts, it might be advantageous to focus on such points as creating a clearer strategic framework and management priority for libraries to play a role in preventive efforts in local communities and enhancing employee readiness and opportunities for potential collaboration with the local community. 
An anthology from Socialstyrelsen (2017) focuses on various aspects of partnerships and cooperation between public and civil society to inspire new forms of cooperation in social work for people with mental difficulties. The anthology mainly reports the results of a State-initiated project to develop and test preventive interventions for people with mental difficulties through partnerships and cooperation between public and civil society.

A study by Espersen et al. (2018) explores how publicly supported national actors can contribute to developing voluntary work. It concludes that a plurality of actors should be supported and that support to the management conditions as well as capacity development of voluntary actors matters.

In sum, the analysis reveals that despite a long tradition in Denmark for collaboration between public sector actors and civil society, the current projects and initiatives are still somehow fragmented and no systematised knowledge is obtained and developed.

\subsection{Theme 3: Social Entrepreneurs and Social Innovation}

A different aspect is a focus on civil society actors and their roles in solving societal problems through social innovation. This literature discusses what social innovation is, how it can become more visible and better organised, how it contributes to public service innovation, who the actors are and what type of planning is involved. Below are some key examples of how this is mirrored in practice.

Bach (2015) studies social enterprises in the Baltic Sea. The study maps stakeholders' and educational initiatives and discusses their impact based on information collected by grassroots organisations that actively contribute to the development of the social economy sector in Denmark, Estonia, Latvia, Lithuania, Sweden, Finland and Poland. The study also conducts an analysis of the social economy and social enterprise landscape in Denmark. It finds that as of 2013, there were an estimated 300 social enterprises employing 3500 full-time workers. A Committee for Social Enterprises was established in 2013, resulting in a government proposal in September 2014 to create more and stronger social enterprises, which included the establishment of a National Centre for Social Enterprises. An act on registered social enterprises was adopted by the Danish Government in 2015.

Damvad Danmark A/S (2012) explores challenges facing social innovation in Danish peripheral and remote regions, thereby aiming to spread good practices for inspiration and learning. Damvad Danmark A/S (2012) defines social innovation as activities carried out with the aim of meeting a societal problem or need that is not otherwise taken care of and that is aimed at delivering new solutions in a more efficient or fair way. The value created by social innovation concerns society as a whole rather than individuals. Social innovation has a cross-sectorial point of departure, and its potential often occurs across sectors, where knowledge and ideas are exchanged between public sector actors, volunteers (civil society) and the private sphere. Therefore, collaborative relations between different actors are central. Social entrepreneurs are seen as individuals who, through their innovative qualities and ability to create social change, provide social innovation in the peripheral regions. The study concludes that (1) social innovation requires an enthusiast/fiery soul, (2) initiatives for social innovation are primarily driven by enthusiasts and NGOs, (3) the composition of the group of participants is paramount, (4) municipalities have a broad impact on social innovation and (5) project funding is important but difficult.

Hulgård et al. (2008) discuss whether alternative workplaces, under special conditions, can function as a good means of integrating the socially disadvantaged. Their report presents various initiatives including the contribution of social enterprises and describes two dilemmas, a moral and a political-administrative dilemma. The moral dilemma is about the schism between doing something specific to certain groups without others having the same access to these services. The political-administrative dilemma is whether abusers, homeless people and others with big and heavy social problems for short or long periods will be able to claim salaries and social benefits at the same time. However, the report argues that it is an empirical fact that such arrangements already exist in practice. 
Kristensen (2012) explores the establishment of a social innovation, Café Clare, a night café for women. The study shows how it has required a long-standing effort. Employees and managers in social services and organisations in the homeless area had more or less strategically made use of and negotiated opportunities for improved efforts for homeless women, including the café. The paper draws on research on social entrepreneurship, public innovation and commercial innovation. It argues that social innovation processes are often characterised by adaptations and changes. In some processes, the goal is formulated in advance. In others, it is more diffuse as in the case of Café Clare, whose shape and content became concretised along the way.

Delica (2016) deals with cultural planning and understands culture, not in a narrow sense as art, but as cultural resources in a broader sense. The paper focuses on the formation of library-based community centres in disintegrated areas in Denmark as a social innovation. It argues that culturised planning can help develop disadvantaged urban areas. The study concludes that the project from library to citizen centre can be seen as cultural planning with a territorial aim with the broad ambition to address non-fulfilled socio-cultural needs. It is then an expression of culturised planning as it enables a practice that goes beyond sectoral divisions and geographically divided areas.

Lauritzen (2012) investigates why municipalities should be interested in social innovation and what their role should be it. Social innovation is seen as a way to solve social challenges by mobilising unused resources often across the public, private and third sectors. Five characteristics must be present to count as social innovation (cf. also Damvad Danmark A/S 2012): it should be new, it should realise the new, it should work, it should be about meeting social needs (e.g., in integration, health, elderly care, etc.) and it should promote society's capacity for action. In addition, the study claims that social innovation is often characterised by open and collaborative approaches, bottom-up approaches, co-production, joint efforts, better use of assets and resources and the formation of new partnerships and can be an important supplement to other instruments such as budget cuts and streamlining. The study concludes that social innovation can potentially contribute to solve problems in areas that municipalities can no longer cover, it can lead to better solutions than the municipalities can provide, and it can reduce the need for increased public income, budget cuts or streamlining.

In sum, the reviewed papers in this section show that in Denmark, there is an interest in the contribution of social actors for addressing public needs through use of social innovation and entrepreneurship. The analysis also demonstrates the experimental character and immaturity of these initiatives and the concern for the administrative and moral dilemmas involved.

\subsection{Theme 4: Public-Private Innovation Partnerships}

According to Brogaard and Petersen (2014), public-private innovation partnerships are often more development- and collaboration-oriented than traditional supplier-buyer relations and put knowledge sharing, common innovation and developing ideas into focus. Public-private innovation partnerships in the Danish theoretical, empirical and grey literature are closer to collaboration than to supplier-buyer relationships.

Brogaard and Petersen (2014) aim to elucidate the challenges, the success criteria as well as the results and effects achieved in public-private innovation partnerships based on eight in-depth case studies across four core welfare areas: health, elderly, day care and education. The findings identify a number of success factors that have been central to implementing the partnerships and the realisation of results and effects, including the criteria for identifying a clear problem to be solved, a commercial potential for the solution, trust and continuous communication among the actors involved rather than a formal cooperation contract, guidelines for handling the procurement rules, enthusiasts that drive cooperation forward and mutual understanding of differences between public and private cultures. Main challenges and barriers instead include a lack of clarification of possible risks in the cooperation, a lack of clarity about the purpose of the project and a lack of 
expectation between the parties at the start of the cooperation. In addition, the analysis shows that limited technical skills and readiness as well as organisational support and engagement can present challenges in relation to implementation and goal achievement. By zooming up on some of the issues of the above study, Brogaard (2015) examines the importance of exogenous, institutional and collaborative factors in public-private innovation partnerships in a comparative case study of four public-private innovation partnerships in the field of health and elderly in Denmark. The results mainly confirm some of the findings of the previous study and show that where innovation is achieved, barriers such as procurement rules are handled through management of cooperation and trust-based relationships. In addition, a collaborative process based on common purpose has contributed to the development and implementation of new solutions.

Another example stems from the municipality of Copenhagen (Kobenhavns Kommune 2011), which initiated a project where seven municipalities, two universities and the organisation Local Government Denmark (KL) collaborated with 100 companies to reduce their greenhouse gas emissions. Cooperation between municipalities and companies took the form of a public-private partnership (PPP), which did not have a legally binding contractual element but was based exclusively on voluntary cooperation between municipalities and companies, and no funding is included as part of the partnership.

In sum, the review reveals the use of public-private partnerships for social innovation in Denmark, yet also a concern for the many challenges involved. Management of cooperation and trust-based relationships are found to be conditions for innovation in these relationships.

\section{Discussion and Conclusions}

There is a basic understanding in the literature that public service innovation should generate public and social value and requires specific processes of cooperation across many actors. Mobilising civic (social) actors is seen as important for creating effective and legitimate solutions. Further, this requires public support and facilitation to overcome barriers.

The above analysis therefore has showed that the concept of public service innovation networks for social innovation (PSINSIs) can be used to identify and analyse studies on social innovation in a Danish context. In the following section, we summarise and discuss our results in relation to the dimensions of the PSINSI framework: the agents involved in the PSINSIs, the role played by the public agents, the nature of the target innovation and, finally, the main sector concerned by the innovation in question.

\subsection{The Types of Agents Involved in the Network}

The analysis shows that at least four types of actors can be identified in networks of public service innovation for social innovation: public sector organisations, social enterprises, civic organisations including volunteers and private companies. Most of the literature refers to the public sector as a dominant agent in such networks (see also below). This result is in accordance with the Nordic eelfare state model of publicly funded and administered egalitarian public services (Esping-Andersen 1990). With regards to the other three actors' statuses and roles, there is more variation in the literature. Part of the literature has a strong focus on social innovation and social economy/social enterprises. The literature is concerned with the role of social enterprises, their contribution to addressing public needs and the dilemmas involved. Another stream of literature gives attention to civic network organisations (small/large) and volunteer groups (including professional volunteers) often with a focus on specific projects and particular service areas. This includes projects with self-help groups, vulnerable families, the handicapped or people with mental difficulties. This literature also examines how the public sector can support voluntary initiatives. Some authors explore public-private partnerships/networks, paying attention to opportunities, barriers and success criteria such as identifying a clear problem to be solved, a commercial potential for the solution, trust and continuous communication (Brogaard and Petersen 2014; Brogaard 2015). The analysis also shows that a particular 
research tradition of collaborative innovation has emerged in the Danish public administration literature. It stresses collaboration between interdependent agents in solving complex problems as a driver of innovation. Public, private and social agents can be part of collaborative innovation efforts.

The literature also shows how the various actors can take different roles in social innovation (Damvad Danmark A/S 2012; Pedersen-Ulrich 2016). Some literature stresses innovation processes rather than innovation outcomes (see Kristensen 2012; Delica 2016). The innovation process is described as a combination of a planned process and an iterative, emergent, involving and mobilising process. Such processes of mobilising social actors for innovation, thereby strengthening peoples' social roles and social capital, may be a goal in itself (Andersen et al. 2014). The literature is also concerned with the inclusion and participation in communities of vulnerable people, such as people with mental difficulties (Socialstyrelsen 2017). The analysis also points out that extensive relations between public sector and social sector have existed for a long time in Denmark (Ibsen and Espersen 2016; Andersen and Espersen 2017). Such relations are of various kinds. Volunteers are involved in many different ways; however, the involvement may sometimes rely on personal relations (Espersen and Olsen 2018). However, the social sector has recently been more emphasised in policies for public innovation as a strategic actor in innovation processes and partnerships.

\subsection{The Role Played by the Public Agent (the Public Administration)}

The analysis shows that the Danish public sector can play at least four different roles (apart from no roles): (1) as a co-producer of services (basically in control of the whole process from creation to delivery), (2) as a service development facilitator and support system (leaving more responsibility to civic actors in the creation and delivery of services), (3) as a complementary service provider (the civic actor provides services independent of, but complementary to public services) and (4) finally as a driving force for the involvement of social actors in innovation and development processes.

In the Danish literature that deals directly with samskabelse and is based on public administration research, the public sector is considered a driving force and is most often involved as a co-producer. In these studies, the public sector takes the initiative, makes decisions, is responsible for implementation and often also delivers the service. In the Danish literature on social enterprises, social entrepreneurship and civic organisations, this is the opposite. Here, the starting point is social actors and opportunities for civil society actors to collaborate with and supplement public services, for example, through the establishment of social enterprises and social networks and through the involvement of volunteers. The literature also analyses how the formation of social enterprises can be supported through public support and how public support can help develop voluntary areas. The public sector's role can be to stimulate civic and social-economic involvement, to advise, facilitate or engage in collaboration with these actors to provide activities and services that complement public services.

The civic actors mobilised for social innovation in public services are described in two ways: as commercial entities (social enterprises) and as networks (including social movements and voluntary groups/people). Social enterprises are often based in a local context, but networks extend sometimes beyond the local level. In many of the examples given in the literature, innovation processes and projects are rooted in a local microecosystem and are not stretching beyond the local level.

\subsection{The Nature of the Targeted Innovation}

Social innovations in the reviewed Danish literature can be characterised as service offerings aimed at supporting specific groups of vulnerable citizens towards living a dignified and meaningful life. The innovations can transpire both in the public sector and in the civil sector. They become integrated with a larger portfolio of public services, yet the social initiatives often lead to local innovations. However, they have the potential to 
inspire activities beyond the local level. Examples include community centres in libraries (Delica 2016) and crime prevention projects (Torfing et al. 2017). This means that many of the social innovations arising out of local activities are not universal public services but solutions that occur locally in an organic relationship with local actors. Thus, in this sense, they break with the Nordic welfare state model. Often volunteers are involved who are mobilised in the local contexts where they live or work. The role of these innovative activities for public sector may be that they inspire other similar activities in other local communities embedded in local networks and activities.

This heterogeneity of social innovation for public services also raises questions of how the impact can be managed and especially measured. Agger et al. (2018) and Torfing et al. (2017) both emphasise the need to develop hard and soft methods for measuring effects of public innovation. The effects measured should include also social innovations, for example, whether the innovative projects solve the problems they set out to solve.

\subsection{The Main Sector Concerned by the Innovation in Question}

The analysis shows that the Danish literature focuses mainly on the implications for the civic and public sectors, with less focus on the implications for the private sector.

In most of the reviewed literature, the public sector is concerned directly and/or indirectly. Most notably in the public administration-oriented literature, the services described are co-developed, co-produced and co-delivered by the public sector. The analysis also shows that some services are developed by social actors to complement public service. However, the upscaling of social innovations developed and delivered by civic actors may be a difficulty. For example, social enterprises are often described as stand-alone micro-enterprises visible only in a local area. They solve problems on the spot by using the available resources in an effective way. Yet their real contribution often remains local.

\subsection{Concluding Remarks}

This article intended to shade light on the perceptions and practices of social innovation in the literature focusing on the Danish public sector through the lenses of the PSINSI construct. To do this, we conducted a thorough literature review of the theoretical and empirical studies as well as the grey literature dealing in a more or less explicit way with this phenomenon. The analysis reveals that the literature deals with either social innovation or public innovation rather than on their interrelatedness and the networked aspect of engaging in social innovation for public innovation.

Finally, the article proposes avenues for future research based on the following research questions that emerged from the literature review: How can social innovation in a public sector context be further conceptualised and developed? How is social innovation for public sector innovation enacted and understood across the EU? What are the potentials of the emerging focus on social innovation for public sector innovation relative to citizen engagement and development of public services?

Author Contributions: Conceptualization, A.S. and L.F.; methodology, A.S.; software, A.S. and L.F.; validation, A.S., L.F.; formal analysis, A.S. and L.F.; investigation, A.S. and L.F.; data curation, A.S. and L.F.; writing —original draft preparation, A.S. and L.F.; writing-review and editing, A.S., L.F, A.V.H., F.G.; visualization, A.S. and L.F. All authors have read and agreed to the published version of the manuscript.

Funding: This project received funding from the the European Union's Horizon 2020 Research and Innovation Programme (grant agreement No. 770356). This publication reflects the views of only the author, and the agency cannot be held responsible for any use that may be made of the information contained therein.

Conflicts of Interest: The authors declare no conflict of interest. The funders had no role in the design of the study; in the collection, analyses or interpretation of data; in the writing of the manuscript; or in the decision to publish the results. 


\section{Appendix A. Search Results}

\begin{tabular}{|c|c|c|c|c|c|}
\hline Search Date & Database & Search Words & \# Hits & Screened & Uploaded \\
\hline $\begin{array}{l}20 / 9 / 18 \\
25 / 9 / 18\end{array}$ & \multirow[t]{2}{*}{ Google } & $\begin{array}{l}\text { Public innovation networks for social } \\
\text { innovation (PSINSIs) }\end{array}$ & $\begin{array}{l}\approx 5.670 \\
\approx 7.430\end{array}$ & 103 & 17 \\
\hline $4 / 10 / 18$ & & By adding "publication" & $\approx 5.010$ & $\begin{array}{l}70 \\
\text { (real hits) }\end{array}$ & 14 \\
\hline $20 / 9 / 18$ & \multirow[t]{2}{*}{ Google } & Collaborative innovation and social innovation & $\approx 90$ & $\begin{array}{l}29 \\
\text { (real hits) }\end{array}$ & 5 \\
\hline $5 / 10 / 18$ & & By adding "publication" & $\approx 59$ & $\begin{array}{l}17 \\
\text { (real hits) }\end{array}$ & 2 \\
\hline $\begin{array}{l}20 / 9 / 18 \\
27 / 9 / 18\end{array}$ & \multirow[t]{2}{*}{ Google } & Public service AND social innovation & $\begin{array}{l}\approx 174 \\
\approx 166\end{array}$ & $\begin{array}{l}61 \\
\text { (real hits) }\end{array}$ & 7 \\
\hline $5 / 10 / 18$ & & By adding "publication" & $\approx 103$ & $\begin{array}{l}30 \\
\text { (real hits) }\end{array}$ & 3 \\
\hline \multirow[t]{2}{*}{$\begin{array}{l}20 / 9 / 18 \\
27 / 9 / 18\end{array}$} & \multirow[t]{2}{*}{ Google } & Public service collaboration with volunteers & $\begin{array}{l}\approx 67.400 \\
\approx 74.700\end{array}$ & & \\
\hline & & By adding "social innovation" & $\approx 18.600$ & $\begin{array}{l}100 \\
\text { (s. 1-10) }\end{array}$ & 14 \\
\hline \multirow{4}{*}{$\begin{array}{l}20 / 9 / 18 \\
1 / 10 / 18 \\
5 / 10 / 18\end{array}$} & \multirow{4}{*}{ Google } & Social innovation AND municipalities & $\approx 39.900$ & 110 & 10 \\
\hline & & & $\approx 38.900$ & (S. 1-10) & \\
\hline & & & $\approx 3.170$ & $\begin{array}{l}100 \\
\text { (S. } 1-10)\end{array}$ & 14 \\
\hline & & By adding "publication" & $\approx 437$ & $\begin{array}{l}78 \\
\text { (real hits) }\end{array}$ & 6 \\
\hline $20 / 9 / 18$ & \multirow{3}{*}{ Google } & Public-private innovation partnership(s) AND & 4 & 6 & 0 \\
\hline $27 / 9 / 18$ & & social innovation & 6 & & \\
\hline $5 / 10 / 18$ & & By adding "publication" & 3 & 3 & 0 \\
\hline
\end{tabular}

Note: Broad Google search to ensure finding both grey and peer-reviewed literature.

\begin{tabular}{|c|c|c|c|c|c|}
\hline Search Date & Database & Search Words & \# Hits & Screened & Uploaded \\
\hline $2 / 10 / 18$ & $\begin{array}{l}\text { Local Government } \\
\text { Denmark (KL) }\end{array}$ & $\begin{array}{l}\text { Public innovation networks for social } \\
\text { innovation (PSINSIs) }\end{array}$ & 3 & 3 & 1 \\
\hline $2 / 10 / 18$ & $\begin{array}{l}\text { Local Government } \\
\text { Denmark (KL) }\end{array}$ & $\begin{array}{l}\text { Collaborative innovation and social } \\
\text { innovation }\end{array}$ & 11 & $\begin{array}{l}3 \\
\text { (real hits) }\end{array}$ & 2 \\
\hline $2 / 10 / 18$ & $\begin{array}{l}\text { Local Government } \\
\text { Denmark (KL) }\end{array}$ & Public service AND social innovation & 328 & 328 & 22 \\
\hline $3 / 10 / 18$ & $\begin{array}{l}\text { Local Government } \\
\text { Denmark (KL) }\end{array}$ & $\begin{array}{l}\text { Public service collaboration with } \\
\text { volunteers }\end{array}$ & 353 & 353 & 19 \\
\hline $3 / 10 / 18$ & $\begin{array}{l}\text { Local Government } \\
\text { Denmark (KL) }\end{array}$ & Social innovation AND municipalities & 625 & 625 & 7 \\
\hline $2 / 10 / 18$ & $\begin{array}{l}\text { Local Government } \\
\text { Denmark (KL) }\end{array}$ & $\begin{array}{l}\text { Public-private innovation partnership(s) } \\
\text { AND social innovation }\end{array}$ & 1 & 1 & $\begin{array}{l}0 \\
\text { (ingen adgang) }\end{array}$ \\
\hline
\end{tabular}

Note: This search resulted into many appendices, minutes from meetings, or public-private partnership (PPP) shows from presentations. Many links cannot be displayed. 


\begin{tabular}{|c|c|c|c|c|c|}
\hline Search Date & Database & Search Words & \# Hits & Screened & Uploaded \\
\hline $\begin{array}{l}2 / 10 / 18 \\
4 / 10 / 18\end{array}$ & $\begin{array}{l}\text { Ministry of the Interior } \\
\text { and Housing }\end{array}$ & $\begin{array}{l}\text { Public innovation networks for social } \\
\text { innovation (PSINSIs) }\end{array}$ & 155 & 155 & 8 \\
\hline $\begin{array}{l}2 / 10 / 18 \\
4 / 10 / 18\end{array}$ & $\begin{array}{l}\text { Ministry of the Interior } \\
\text { and Housing }\end{array}$ & $\begin{array}{l}\text { Collaborative innovation and social } \\
\text { innovation }\end{array}$ & 345 & 345 & 17 \\
\hline $\begin{array}{l}2 / 10 / 18 \\
4 / 10 / 18\end{array}$ & $\begin{array}{l}\text { Ministry of the Interior } \\
\text { and Housing }\end{array}$ & Public service AND social innovation & 350 & 350 & 0 \\
\hline $\begin{array}{l}2 / 10 / 18 \\
4 / 10 / 18\end{array}$ & $\begin{array}{l}\text { Ministry of the Interior } \\
\text { and Housing }\end{array}$ & $\begin{array}{l}\text { Public service collaboration with } \\
\text { volunteers }\end{array}$ & 161 & 161 & 0 \\
\hline $\begin{array}{l}2 / 10 / 18 \\
4 / 10 / 18\end{array}$ & $\begin{array}{l}\text { Ministry of the Interior } \\
\text { and Housing }\end{array}$ & Social innovation AND municipalities & 103 & 103 & 0 \\
\hline $\begin{array}{l}2 / 10 / 18 \\
4 / 10 / 18\end{array}$ & $\begin{array}{l}\text { Ministry of the Interior } \\
\text { and Housing }\end{array}$ & $\begin{array}{l}\text { Public-private innovation } \\
\text { partnership(s) AND social innovation }\end{array}$ & 345 & 345 & 2 \\
\hline
\end{tabular}

Note: KonjunkturNyt, economic analysis and statements and review of budgets are not included.

\begin{tabular}{|c|c|c|c|c|c|}
\hline Search Date & Database & Search Words & \# Hits & Screened & Uploaded \\
\hline $3 / 10 / 18$ & $\begin{array}{l}\text { Ministry of Social Affairs } \\
\text { and Senior Citizens }\end{array}$ & $\begin{array}{l}\text { Public innovation networks for social } \\
\text { innovation (PSINSIs) }\end{array}$ & 110 & 110 & 46 \\
\hline $3 / 10 / 18$ & $\begin{array}{l}\text { Ministry of Social Affairs } \\
\text { and Senior Citizens }\end{array}$ & $\begin{array}{l}\text { Collaborative innovation and social } \\
\text { innovation }\end{array}$ & 131 & 131 & 6 \\
\hline $3 / 10 / 18$ & $\begin{array}{l}\text { Ministry of Social Affairs } \\
\text { and Senior Citizens }\end{array}$ & Public service AND social innovation & 132 & 132 & 3 \\
\hline $3 / 10 / 18$ & $\begin{array}{l}\text { Ministry of Social Affairs } \\
\text { and Senior Citizens }\end{array}$ & $\begin{array}{l}\text { Public service collaboration with } \\
\text { volunteers }\end{array}$ & 93 & 93 & 1 \\
\hline $3 / 10 / 18$ & $\begin{array}{l}\text { Ministry of Social Affairs } \\
\text { and Senior Citizens }\end{array}$ & $\begin{array}{l}\text { Social innovation AND } \\
\text { municipalities }\end{array}$ & 85 & 85 & 0 \\
\hline $3 / 10 / 18$ & $\begin{array}{l}\text { Ministry of Social Affairs } \\
\text { and Senior Citizens }\end{array}$ & $\begin{array}{l}\text { Public-private innovation } \\
\text { partnership(s) AND social innovation }\end{array}$ & 131 & 131 & 0 \\
\hline
\end{tabular}

Note: Social policy statements and welfare policy analysis are not included.

\begin{tabular}{|c|c|c|c|c|c|}
\hline Search Date & Database & Search Words & \# Hits & Screened & Uploaded \\
\hline $2 / 10 / 18$ & Kora.dk & $\begin{array}{l}\text { Public innovation networks for social innovation (PSINSIs) } \\
\text { Søgt på dansk og engelsk titel }\end{array}$ & 0 & 0 & 0 \\
\hline $2 / 10 / 18$ & Kora.dk & Collaborative innovation and social innovation & 0 & 0 & 0 \\
\hline $2 / 10 / 18$ & Kora.dk & Public service AND social innovation & 4 & 4 & 1 \\
\hline $2 / 10 / 18$ & Kora.dk & Public service collaboration with volunteers & 6 & 6 & 0 \\
\hline $2 / 10 / 18$ & Kora.dk & Social innovation AND municipalities & 6 & 6 & 1 \\
\hline $2 / 10 / 18$ & Kora.dk & $\begin{array}{l}\text { Public-private innovation partnership(s) AND social } \\
\text { innovation }\end{array}$ & 5 & 5 & 0 \\
\hline $4 / 10 / 18$ & VIVE.dk & Public innovation networks for social innovation (PSINSIs) & 0 & 0 & 0 \\
\hline $4 / 10 / 18$ & VIVE.dk & Collaborative innovation and social innovation & 0 & 0 & 0 \\
\hline $4 / 10 / 18$ & VIVE.dk & Public service AND social innovation & 0 & 0 & 0 \\
\hline $4 / 10 / 18$ & VIVE.dk & Public service collaboration with volunteers & 0 & 0 & 0 \\
\hline $4 / 10 / 18$ & VIVE.dk & Social innovation AND municipalities & 0 & 1 & 0 \\
\hline $4 / 10 / 18$ & VIVE.dk & $\begin{array}{l}\text { Public-private innovation partnership(s) AND social } \\
\text { innovation }\end{array}$ & 0 & 0 & 0 \\
\hline
\end{tabular}

Note: KORA, the National Institute for Local Government Analysis and Research, was a Danish analysis and research organisation. The first of July 2017, KORA and the National Research Center for Welfare (SFI) were merged into VIVE-The Danish Center for Social Science Research, and KORA as an independent organisation was closed down in 2019. 


\begin{tabular}{|c|c|c|c|c|c|}
\hline Search Date & Database & Search Words & \# Hits & Screened & Uploaded \\
\hline $3 / 10 / 18$ & $\begin{array}{l}\text { Danish National } \\
\text { Research Database }\end{array}$ & $\begin{array}{l}\text { Public innovation networks for social innovation } \\
\text { (PSINSIs) }\end{array}$ & 22 & 0 & 0 \\
\hline $3 / 10 / 18$ & $\begin{array}{l}\text { Danish National } \\
\text { Research Database }\end{array}$ & Collaborative innovation and social innovation & 21 & 0 & 0 \\
\hline $3 / 10 / 18$ & $\begin{array}{l}\text { Danish National } \\
\text { Research Database }\end{array}$ & Public service AND social innovation & 9 & 0 & 0 \\
\hline $3 / 10 / 18$ & $\begin{array}{l}\text { Danish National } \\
\text { Research Database }\end{array}$ & Public service collaboration with volunteers & 1 & 0 & 0 \\
\hline $3 / 10 / 18$ & $\begin{array}{l}\text { Danish National } \\
\text { Research Database }\end{array}$ & Social innovation AND municipalities & 138 & 0 & 0 \\
\hline $3 / 10 / 18$ & $\begin{array}{l}\text { Danish National } \\
\text { Research Database }\end{array}$ & $\begin{array}{l}\text { Public-private innovation partnership(s) AND } \\
\text { social innovation }\end{array}$ & 1 & 0 & 0 \\
\hline
\end{tabular}

Note: The Danish National Research Database, a joint search service for the local research databases of the Danish research institutions, has been discontinued in January 2021. These were all duplicates.

\begin{tabular}{llllll}
\hline Search Date & Database & Search Words & \# Hits & Screened & Uploaded \\
\hline $3 / 10 / 18$ & Bibliotek.dk & $\begin{array}{l}\text { Public innovation networks for social innovation } \\
\text { (PSINSIs) }\end{array}$ & 79 & 0 & 0 \\
\hline $3 / 10 / 18$ & Bibliotek.dk & Collaborative innovation and social innovation & 6 & 0 & 0 \\
\hline $3 / 10 / 18$ & Bibliotek.dk & Public service AND social innovation & 9 & 0 & 0 \\
\hline $3 / 10 / 18$ & Bibliotek.dk & Public service collaboration with volunteers & 7 & 0 & 0 \\
\hline $3 / 10 / 18$ & Bibliotek.dk & Social innovation AND municipalities & 36 & 0 & 0 \\
$3 / 10 / 18$ & Bibliotek.dk & $\begin{array}{l}\text { Public-private innovation partnership(s) } \\
\text { (without “social innovation" as there were no hits with } \\
\text { this on the full line) }\end{array}$ & 7 & 0 & 0
\end{tabular}

Note: Bibliotek.dk is a portal for all Danish libraries (public libraries, specialised libraries and academic libraries). These were all duplicates.

\section{Appendix B. List of Selected Studies Included in the Review}

1. Agger, A. and Tortzen, A. 2015. Forsknings review om samskabelse. Roskilde: Roskilde Universitet and University College Lillebælt.

2. Agger, A., Tortzen, A. and Rosenberg, C. 2018. Hvilken værdi skaber vi med samskabelseog hoordan kan den måles og dokumenteres? Roskilde: University College Absalon.

3. Andersen, L. L. and Espersen, H. H. 2017. 'Samskabelse, samproduktion og partnerskaber -teoretiske perspektiver', in Socialstyrelsen (ed.), Partnerskaber og samarbejder mellem det offentlige og civilsamfundet. Odense: Socialstyrelsen, pp. 107-137.

4. Andersen, L. L., Fæster, M., Bisballe, L., Grander, M. and Björg, F. 2014. Samarbejde omkring unges indtraeden på arbejdsmarkedet: En tværsektoriel Øresundsmodel. Roskilde: Interreg IV A.

5. Ankestyrelsen. 2010. §18-Redegørelsen 2009: Det kommunale samarbejde med frivillige sociale foreninger - En kvantitativ analyse af kommunernes fordeling af \$18-midler. København: Socialministeriet.

6. Ankestyrelsen. 2013. §18-Redegørelsen: Det kommunale samarbejde med frivillige sociale foreninger-En kvantitativ analyse af kommunernes fordeling af §18-midler. København: Social-, Børne- og Integrationsministeriet.

7. Bach, P. 2015. Socialøkonomiske virksomheder-øjebliksbillede fra landene omkring det Baltiske Hav. Aarhus: Sociale entreprenører i Danmark/Social Entrepreneurship Support Network of the Baltic Sea Region.

8. Brogaard, L. 2015. 'Drivkræfter og barrierer i offentlige-private innovationspartnerskaber (OPI) på sundheds- og ældreområdet i Danmark’. Politica 47(4), 541-560. 
9. Brogaard, L. and Petersen, O. H. 2014. Offentlige-private innovationspartnerskaber (OPI) - Evaluering af erfaringer med OPI på velfxrdsområdet. København: KORA.

10. Damvad Danmark, A. S. 2012. Social innovation og sociale entreprenører i yderområder: Et inspirationskatalog med danske eksempler. København: Ministeriet for By, Bolig og Landdistrikter.

11. Delica, K. N. 2016. 'Kulturplanlægning som social innovation: om udvikling af biblioteksbaserede medborgercentre i udsatte boligområder i Danmark'. Nordisk Kulturpolitisk Tidskrift, 19(2), 163-182.

12. Espersen, H. H. 2016. Evaluering af samarbejdet i projekt Bogstart-En opsøgende biblioteksindsats over for familier med før-skolebørn $i$ udsatte boligområder. København: KORA.

13. Espersen, H. H. and Olsen, L. 2018. At skabe deltagelse for borgere med handicap gennem frivillig faglighed - Evaluering af to partnerskaber mellem kommuner, frivilligcentre og andre aktører. København: VIVE.

14. Espersen, H. H., Andersen, L. L., Olsen, L. and Tortzen, A. 2018. Understøttelse og udvikling af det frivillige sociale arbejde - En analyse af udviklingstendenser og behov for kontinuitet og forandring i nationale virkemidler. København: VIVE.

15. Hulgård, L., Bisballe, L., Andersen, L. L. and Spear, R. 2008. Alternativ beskæftigelse og integration af socialt udsatte grupper - erfaringer fra Danmark og Europa. Roskilde: CSE, RUC.

16. Ibsen, B. and Espersen, H. H. 2016. Kommunernes samarbejde med civile aktører - Forskelle og ligheder i forventninger, praksis, samarbejdspartnere og oplevet udbytte. København: Københavns Kommune.

17. Kristensen, C. J. 2012. Social innovation $\mathrm{i}$ indsatsen for hjemløse kvinder - tilblivelsen af en natcafé. Dansk Sociologi 23(4), 55-73.

18. Københavns Kommune. 2011. OPP og projektets tilgang til samarbejde mellem kommuner og virksomheder Udarbejdet af Københavns Kommune. København: Københavns Kommune.

19. Lauritzen, J. R. K. 2012. Social innovation i kommunerne. Aarhus: Teknologisk Institut, Center for Analyse og Erhvervsfremme.

20. Mandag Morgen. 2011. Guide til fremtidens velfærdsalliancer-gode råd til samarbejde om social forebyggelse. København: Mandag Morgen Innovation.

21. Pedersen-Ulrich, J. 2016. Samskabelse - en typologi. CLOU Skriftserie VIA University College 1(2016), 1-15.

22. Socialstyrelsen. 2017. Partnerskaber og samarbejder mellem det offentlige og civilsamfundet. Støtte til mennesker med psykiske vanskeligheder. Odense: Socialstyrelsen.

23. Torfing, J., Krogh, A. H. and Ejrnæs, A. 2017. Samarbejdsdrevet innovation i kriminalpræventive indsatser: Slutrapport om sammenhængene mellem samarbejde, innovation og kriminalpræventiv effekt og måling heraf. Roskilde: Roskilde Universitet.

\section{References}

Agger, Annika, and Dorthe Hedensted Lund. 2017. Collaborative Innovation in the Public Sector-New Perspectives on the Role of Citizens? Scandinavian Journal of Public Administration 21: 17-37.

Agger, Annika, and Anne Tortzen. 2015. Forsknings Review om Samskabelse. Roskilde: Roskilde Universitet and University College Lillebælt.

Agger, Annika, Anne Tortzen, and Charlotte Rosenberg. 2018. Hvilken Vxrdi Skaber vi Med Samskabelse-Og Hvordan kan den Måles og Dokumenteres? Roskilde: University College Absalon.

Andersen, Linda Lundgaard, and Helle Hygum Espersen. 2017. Samskabelse, samproduktion og partnerskaber-Teoretiske perspektiver. In Partnerskaber og Samarbejder Mellem det Offentlige og Civilsamfundet. Edited by Socialstyrelsen. Odense: Socialstyrelsen, pp. 107-37.

Andersen, Linda Lundgaard, Monika Fæster, Lise Bisballe, Martin Grander, and Fredrik Björg. 2014. Samarbejde Omkring Unges Indtraeden på Arbejdsmarkedet: En Tværsektoriel Øresundsmodel. Roskilde: Interreg IV A.

Ankestyrelsen. 2010. \$18-Redegørelsen 2009: Det Kommunale Samarbejde Med Frivillige Sociale Foreninger-En Kvantitativ Analyse af Kommunernes Fordeling af §18-Midler. København: Socialministeriet.

Ankestyrelsen. 2013. §18-Redegørelsen: Det Kommunale Samarbejde Med Frivillige Sociale Foreninger—En Kvantitativ Analyse af Kommunernes Fordeling af §18-Midler. København: Social Børneog Integrationsministeriet. 
Bach, Per. 2015. Socialøkonomiske Virksomheder—Øjebliksbillede fra Landene Omkring det Baltiske Hav. Aarhus: Sociale entreprenører i Danmark/Social Entrepreneurship Support Network of the Baltic Sea Region.

Bekkers, Victor, Hein Van Duivenboden, and Marcel Thaens. 2006. Public Innovation and Communication technology: Relevant backgrounds and concepts. In Information and Communication Technology and Public Innovation. Amsterdam: IOS Press, pp. 3-21.

Bekkers, Victor, Jurian Edelenbos, José Nederhand, Bram Steijn, Lars Tummers, and William Voorberg. 2014. The Social Innovation Perspective in the Public Sector: Co-creation, Self-organization and Meta-Governance. In Innovation in the Public Sector: Linking Capacity and Leadership. Edited by Victor Bekkers, Jurian Edelenbos and Bram Steijn. London: Palgrave McMillan, pp. $223-43$.

Braun, Virginia, and Victoria Clarke. 2006. Using thematic analysis in psychology. Qualitative Research in Psychology 3: 77-101. [CrossRef]

Brogaard, Linda. 2015. Drivkræfter og barrierer i offentlige-private innovationspartnerskaber (OPI) på sundheds- og ældreområdet i Danmark. Politica 47: 541-60.

Brogaard, Linda, and Ole Helby Petersen. 2014. Offentlige-Private INNOVATIONSPARTNERSKABER (OPI)—Evaluering af Erfaringer Med OPI på Velfærdsområdet. København: KORA.

Cooper, Harris. 1998. Synthesizing Research: A Guide for Literature Reviews, 3rd ed. Thousand Oaks: Sage Publications.

Crosby, Barbara C., Paul 't Hart, and Jacob Torfing. 2017. Public value creation through collaborative innovation. Public Management Review 21: 655-69. [CrossRef]

Damvad Danmark A/S. 2012. Social Innovation og Sociale Entreprenører $i$ Yderområder: Et Inspirationskatalog Med Danske Eksempler. København: Ministeriet for by Bolig og Landdistrikter.

Delica, Kristian Nagel. 2016. Kulturplanlægning som social innovation: Om udvikling af biblioteksbaserede medborgercentre i udsatte boligområder i Danmark. Nordisk Kulturpolitisk Tidskrift 19: 163-82. [CrossRef]

Desmarchelier, Benoit, Faridah Djellal, and Faïz Gallouj. 2019. Innovation in public services in the light of public administration paradigms and service innovation perspectives. European Review of Services Economics and Management 8: 91-120.

Desmarchelier, Benoit, Faridah Djellal, and Faïz Gallouj. 2020. Towards a servitization of innovation networks: A mapping. Public Management Review 22: 1368-97. [CrossRef]

Djellal, Faridah, and Faïz Gallouj, eds. 2018. Fifteen challenges for service innovation studies. In A Research Agenda for Service Innovation. Cheltenham: Edward Elgar Publishers, pp. 1-25.

Espersen, Helle Hygum. 2016. Evaluering af Samarbejdet i Projekt Bogstart-En Opsøgende Biblioteksindsats over for Familier Med FørSkolebørn i Udsatte Boligområder. København: KORA.

Espersen, Helle Hygum, and Lars Olsen. 2018. At Skabe Deltagelse for Borgere Med Handicap Gennem Frivillig Faglighed-Evaluering af to Partnerskaber Mellem Kommuner, Frivilligcentre og Andre Aktører. København: VIVE.

Espersen, Helle Hygum, Linda Lundgaard Andersen, Lars Olsen, and Anne Tortzen. 2018. Understøttelse og Udvikling af det Frivillige Sociale Arbejde-En Analyse af Udviklingstendenser og Behov for Kontinuitet og Forandring i Nationale Virkemidler. København: VIVE.

Esping-Andersen, Gosta. 1990. The Three Worlds of Welfare Capitalism. Cambridge: Polity.

Gallouj, Faiz, Luis Rubalcaba, Marja Toivonen, and Paul Windrum. 2018. Understanding social innovation in services industries. Industry and Innovation 25: 551-69. [CrossRef]

Halvorsen, Thomas, Johan Hauknes, Ian Miles, and Rannveig Røste. 2005. On the Differences between Public and Private Sector Innovation. PUBLIN Report D9. Oslo: NIFU STEP.

Hartley, Jean. 2005. Innovation in governance and public services: Past and present. Public Money and Management 25: 27-34.

Hulgård, Lars, Lise Bisballe, Linda Lundgaard Andersen, and Roger Spear. 2008. Alternativ Beskxftigelse og Integration af Socialt Udsatte Grupper-Erfaringer fra Danmark og Europa. Roskilde: CSE, RUC.

Ibsen, Bjarne, and Helle Hygum Espersen. 2016. Kommunernes Samarbejde Med Civile Aktører-Forskelle og Ligheder i Forventninger, Praksis, Samarbejdspartnere og Oplevet Udbytte. København: Københavns Kommune.

Keast, Robyn, Kerry Brown, and Myrna Mandell. 2007. Getting the right mix; unpacking integration meanings and strategies. International Public Management Journal 10: 9-33. [CrossRef]

Kelly, Gavin, Geoff Mulgan, and Stephen Muers. 2002. Creating Public Value: An Analytical Framework for Public Service Reform. London: Cabinet Office Strategy Unit, United Kingdom Cabinet Office.

Københavns Kommune. 2011. OPP og Projektets Tilgang til Samarbejde Mellem Kommuner og Virksomheder Udarbejdet af Københavns Kommune. København: Københavns Kommune.

Kristensen, Catharina Juul. 2012. Social innovation i indsatsen for hjemløse kvinder-Tilblivelsen af en natcafé. Dansk Sociologi 23: 55-73. [CrossRef]

Lauritzen, John René Keller. 2012. Social Innovation i Kommunerne. Aarhus: Teknologisk Institut, Center for Analyse og Erhvervsfremme.

Martin, Ben. 2015. Twenty Challenges for Innovation Studies. SPRU Working Paper Series. SWPS 2015-30; Oxford: Oxford University Press.

Mergel, Ines. 2018. Open innovation in the public sector: Drivers and barriers for the adoption of Challenge.gov. Public Management Review 20: 726-45. [CrossRef]

OECD. 2000. LEED Forum on Social Innovations. Available online: http:/ /www.oecdorg/document/53/0,3343,fr26493445939263221 1111,00.html-28k- (accessed on 14 December 2020).

Osborne, Stephen. 2006. The New Public Governance? Public Management Review 8: 377-88. [CrossRef]

Osborne, Stephen, ed. 2010. The New Public Governance? London: Routledge. 
Paez, Arsenio. 2017. Gray literature: An important resource in systematic reviews. Journal of Evidence-Based Medicine 10: 233-40. [CrossRef]

Pedersen-Ulrich, Jens. 2016. Samskabelse-En typologi. CLOU Skriftserie VIA University College 1: 1-15.

Pestoff, Victor, Stephen P. Osborne, and Taco Brandsen. 2006. Patterns of co-production in public services: Some concluding thoughts. Public Management Review 8: 591-95. [CrossRef]

Scupola, Ada, and Antonello Zanfei. 2016. Governance and innovation in public sector services: The case of digital library. Government Information Quarterly 33: 237-49. [CrossRef]

Sengupta, Subhanjan, Arunaditya Sahay, and Francesca Croce. 2017. Conceptualizing social entrepreneurship in the context of emerging economies: An integrative review of past research from BRIICS. International Entrepreneurship and Management Journal 14: 771-803. [CrossRef]

Simon, Julie, Jeremy Millard, John René Keller Lauritzen, Gwendolyn Carpenter, Gudrun Schimpf, and Przemysław Leszek. 2015. Doing Social Innovation: A Guide for Practitioners. A Deliverable of the Project: "The Theoretical, Empirical and Policy Foundations for Building Social Innovation in Europe" (TEPSIE). European Commission-7th Framework Programme. Brussels: European Commission.

Socialstyrelsen. 2017. Partnerskaber og Samarbejder Mellem det Offentlige og Civilsamfundet. Støtte til Mennesker Med Psykiske Vanskeligheder. Odense: Socialstyrelsen.

Sørensen, Eva, and Jacob Torfing. 2011. Samarbejdsdrevet Innovation i den Offentlige Sektor. København: DJØF-forlaget.

Sørensen, Eva, and Jacob Torfing. 2013. Enhancing Social Innovation by Rethinking Collaboration, Leadership and Public Governance. Paper presented at NESTA Social Frontiers, London, UK, December 10.

Swank, Duane. 2000. Social democratic welfare states in a global economy: Scandinavia in comparative perspective. In Globalization, Europeanization and the End of Scandinavian Social Democracy? Edited by Robert Geyer, Christine Ingebritsen and Jonathon Moses. London: Palgrave Macmillan.

Torfing, Jacob. 2016. Collaborative Innovation in the Public Sector. Washington, DC: Georgetown University Press.

Torfing, Jacob. 2019. Collaborative innovation in the public sector: The argument. Public Management Review 21: 1-11. [CrossRef]

Torfing, Jacob, Andreas Hagedorn Krogh, and Anders Ejrnæs. 2017. Samarbejdsdrevet Innovation i Kriminalpræventive Indsatser: Slutrapport om Sammenhængene Mellem Samarbejde, Innovation og Kriminalpræventiv Effekt og Måling Heraf. Roskilde: Roskilde Universitet.

Voorberg, William H., Viktor JJM Bekkers, and Lars G. Tummers. 2015. A systematic review of co-creation and co-production: Embarking on the social innovation journey. Public Management Review 17: 1333-57. [CrossRef]

Webster, Jane, and Richard T. Watson. 2002. Analyzing the past to prepare for the future: Writing a literature review. MIS Quarterly 26: xiii-xxiii.

Whittemore, Robin, and Kathleen Knafl. 2005. The integrative review: Updated methodology. Journal of Advanced Nursing 52: 546-53. [CrossRef] [PubMed] 